Tropical Journal of Pharmaceutical Research February 2019; 18 (2): 279-286

ISSN: $1596-5996$ (print); 1596-9827 (electronic)

(c) Pharmacotherapy Group, Faculty of Pharmacy, University of Benin, Benin City, 300001 Nigeria.

\title{
Comparative studies on flavor substances of leaves and pericarps of Zanthoxylum bungeanum Maxim. at different harvest periods
}

\author{
Lei Zhu, Li Wang, Xi Chen, Wei Peng, Yujie Liu, Linying Yu, Fang Liang, \\ Chunjie Wu* \\ College of Pharmacy, Chengdu University of Traditional Chinese Medicine, No. 1166 Liutai Avenue, Chengdu 610075, PR \\ China
}

${ }^{\star}$ For correspondence: Email: wucjcdtcm@163.com; Tel: +86-028-61801001

Sent for review: 7 August 2018

Revised accepted: 5 January 2019

\begin{abstract}
Purpose: To study the transformation of the aroma components and pungent constituents of Zanthoxylum bungeanum Maxim. (ZBM) leaves and pericarps at different periods, and to provide a basis for selecting an appropriate harvest time for the pericarps and leaves.

Methods: Quantitative analysis of the pungent components of ZBM leaves and pericarps was performed by high performance liquid chromatography (HPLC) while their aroma constituents were analyzed by headspace solid phase micro-extraction combined with gas chromatography-mass spectrometry (HS-SPME-GC-MS).

Results: HPLC analysis revealed that hydroxy- $\alpha$-sanshool was the predominant pungent component in both the leaves and pericarps of different parts of ZBM at different harvest periods, followed by hydroxy$\gamma$-sanshool and hydroxy- $\beta$-sanshool. During the growth of ZBM, the contents of pungent substances in the leaves declined gradually, while pungent substances in the pericarps increased. The results of HSSPME-GC-MS analysis showed that linalyl acetate, linalool and limonene were the major aroma components of the leaves and pericarps of ZBM at different harvest periods. During the growth of ZBM, the contents of monoterpenes in the leaves decreased gradually, whereas monoterpenes in the pericarps increased.

Conclusion: These results suggest that the pungent and aroma components produced in ZBM at early developmental stages are stored in the leaves, and are gradually transferred to the pericarps at the final developmental stages. Thus, the leaves of ZBM can be used as a new source of food and medicine.
\end{abstract}

Keywords: Zanthoxylum bungeanum Maxim., Pericarp, Pungent components, Aroma components

This is an Open Access article that uses a funding model which does not charge readers or their institutions for access and distributed under the terms of the Creative Commons Attribution License (http://creativecommons.org/licenses/by/4.0) and the Budapest Open Access Initiative (http://www.budapestopenaccessinitiative.org/read), which permit unrestricted use, distribution, and reproduction in any medium, provided the original work is properly credited.

Tropical Journal of Pharmaceutical Research is indexed by Science Citation Index (SciSearch), Scopus, International Pharmaceutical Abstract, Chemical Abstracts, Embase, Index Copernicus, EBSCO, African Index Medicus, JournalSeek, Journal Citation Reports/Science Edition, Directory of Open Access Journals (DOAJ), African Journal Online, Bioline International, Open-J-Gate and Pharmacy Abstracts

\section{INTRODUCTION}

The pericarp of Zanthoxylum is commonly named Huajiao or Szechuan pepper, and the most popular commercially goods are "honghuajiao" and "qinghuajiao" in China. The "qinghuajiao" is derived from the green pericarps of Zanthoxylum armatum DC. and Zanthoxylum schinifolium Sieb. et Zucc., which are used for food seasoning. Another type of "honghuajiao" is 
derived from the bright red pericarp of the Zanthoxylum bungeanum Maxim. (ZBM), which is the most popular commercial product in the genus Zanthoxylum, with a long history of application as a popular condiment in cooking and medicine in China [1].

The pericarps of ZBM are widely used as a flavor condiment, and also as traditional Chinese medical herbs for their therapeutic properties such as a warming action, relieving pain, dispelling dampness, stopping diarrhea, and preventing itch [1]. Flavor substances (aroma constituents and pungent components), are mainly responsible for these pharmacological activities. Essential oils are the principle source of the special fragrant odor in huajiao. It has a variety of effects such as antibacterial, antifungal, antiviral, insecticidal, antithrombotic, antiatherosclerosis, etc [2,3].

The tingling sensation of huajiao is a unique pungent taste, known as "ma". Furthermore, constituents responding for the special taste of "ma" are unsaturated fatty acid amides of sanshool, especially the hydroxy-a-sanshool, hydroxy- $\beta$-sanshool, and hydroxy- $y$-sanshool etc, and possess various pharmacological activities such as antitumor, insecticidal, anti-inflammatory, anesthetic and analgesic properties, etc. [4-7]. In addition, the leaves of ZBM is widely utilized in food seasonings because of its unique aroma and taste which are similar to the flavor of the pericarps of ZBM [1].

The flavor substances in ZBM are not only the basic ingredients of the seasonings, but also the active ingredients responding for its pharmacological activities. Although the flavor substances, including the aroma components and the pungent components, have been identified in many previous studies, little information is available about changes in the potent flavor substances of laves and pericarps of ZBM as a function of $t$ harvest periods. The scarcity of available data prompted us to reinvestigate the aroma constituents and numbtaste components of ZBM pericarps and leaves.

In the present study, comparison of the aroma components and the pungent components of ZBM leaves and pericarps at different harvest periods by high performance liquid chromatography (HPLC) and headspace solid phase micro-extraction combined with gas chromatography-mass spectrometry (HS-SPMEGC-MS) analyses. In addition, the possibility of translocation of the flavor substances between the leaves and the pericarps was studied.

\section{EXPERIMENTAL}

\section{Plant materials}

In order to study the flavor substances of leaves and pericarps of ZBM at different harvest periods, samples were collected samples at three different time points on the same tree (Figure 1). The fruits and leaves of ZBM were collected from the same tree in Hanyuan, Sichuan province, China in 2017. The young fruits and leaves were harvested on May 20, and the half-mature fruits and leaves were obtained on June 27, while the mature fruits and leaves were gathered on August 8. The fresh leaves and fruits were dried at $40{ }^{\circ} \mathrm{C}$ for $6 \mathrm{~h}$. The pericarp of the dried fruits was separated from the seeds and used for further analyses. The dried pericarps and leaves were vacuum sealed and refrigerated.

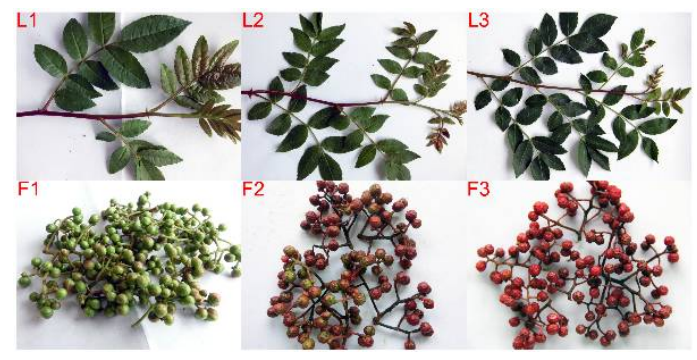

Figure 1: Plant materials used. L1: young leaves; L2: half-mature leaves; L3: mature leaves; F1: young fruits; F2: half-mature fruits; F3: mature fruits

\section{Chemicals and reagents}

Hydroxy- $\alpha$-sanshool, hydroxy- $\beta$-sanshool, and hydroxy-y-sanshool were all made in-house. They were identified by NMR and consistent with the literature (Mizutani et al., 1988). The purity of the sample was determined using HPLC peak area normalization method greater than $98.5 \%$. Methanol and acetonitrile HPLC grade were bought from Sigma (St. Louis, MO, USA). Water was distilled using a UPT water purification system (Ulupure Corporation, Chengdu, China).

\section{Apparatus}

The quantitative analysis of the pungent components was performed with Shimadzu liquid chromatographic system (Shimadzu LC-2010A, Japan) consisting of SIL-20A autosampler, SPD20A detector, CTO-20A Column Thermostat, LC solution Chromatography Workstation Software. The analytical column was Phenomenex C18 $(250 \mathrm{~mm} \times 4.6 \mathrm{~mm}, 4 \mu \mathrm{m}$ particle size). Aroma components analysis was accomplished by HSSPME-GC-MS system comprising AOC-6000 headspace sampler (Shimadzu, Japan), HP- 
1510 gas chromatography headspace heater (Jicheng Analytical Instrument Company, Shanghai, China.), solid phase microextraction

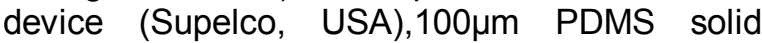
phase microextraction fiber (Supelco, USA), Shimadzu gas chromatography system(Shimadzu, GC-2010, Japan), Shimadzu mass spectrometer (Shimadzu, TQ-8040, Japan), and GC-MS solution Chromatography Workstation Software. The components were separated on an Agilent DB-17MS column (30m $\times 0.25 \mathrm{~mm} \times 0.25 \mu \mathrm{m}$ film thickness) (Agilent Technologies, USA).

\section{Preparation of samples and standards}

\section{Mixed standard solutions}

Reference stock solutions of hydroxy- $\alpha$ sanshool, hydroxy- $\beta$-sanshool and hydroxy- $\gamma-$ sanshool $(400,10$, and $25 \mu \mathrm{g} / \mathrm{mL})$ in methanol were prepared in a $10-\mathrm{mL}$ volumetric flask. Then, $2 \mathrm{~mL}$ of each reference stock was diluted to $10 \mathrm{~mL}$ with methanol in a $10-\mathrm{mL}$ volumetric flask to yield mixed standard solutions. The mixed standard solution were then serially diluted in a series of concentrations [9]. The lowest concentration of the reference solution was serially diluted, with signal-to-noise ratios of 3 and 10 as detection and quantitation limits, respectively.

\section{Pungent substance samples}

The dried pericarps and leaves of ZBM were ground to powder, passed through a sieve of 355 $\mu \mathrm{m}$ pore size, and used as sample powders. Half a gram sample (accurate to $0.0001 \mathrm{~g}$ ) was accurately weighed into a sealed Erlenmeyer flask and ultrasonically extracted with $50 \mathrm{~mL}$ of methanol for $30 \mathrm{~min}$. Each sample extract was analyzed in triplicate. In the preliminary experiments, the contents of pungent substances in the half-mature and mature pericarps of ZBM were found to be quite different from those of other samples. In order to ensure the accuracy of experimental data, the total volume of each extract was adjusted to $500 \mathrm{~mL}$ in the case of half-mature pericarps, and to $1000 \mathrm{~mL}$ for mature pericarps, while $50 \mathrm{~mL}$ was used for other samples. The solvent used was methanol. The solutions were filtered through a $0.45-\mu \mathrm{m}$ microporous membrane into the injection bottle prior to use.

\section{High performance liquid chromatography}

Chromatographic separation was performed in a column (Phenomenex C18) with a detection wavelength of $270 \mathrm{~nm}$. The column temperature was maintained at $30^{\circ} \mathrm{C}$. The mobile phase used for analyzing the three hydroxyl sanshools by HPLC was acetonitrile: water at a volume ratio of $=40: 60$ for $55 \mathrm{~min}$, at a flow rate of $1.0 \mathrm{~mL} / \mathrm{min}$ and injection volume of $10 \mu \mathrm{L}$.

\section{Construction of reference standard curve}

For the HPLC analysis, a series concentration reference solution $(10 \mu \mathrm{l})$ was injected into the HPLC. Taking the peak area as the ordinate and the solution mass concentration as the abscissa for linear regression, the regression equations for hydroxy- $\alpha$-sanshool, hydroxy- $\beta$-sanshool, and hydroxy- $y$-sanshool were obtained.

\section{HS-SPME-GC-MS}

In this procedure, $0.3 \mathrm{~g}$ of the sample powder was accurately weighed into a headspace vial, sealed and incubated for 30 minutes at a temperature of $50{ }^{\circ} \mathrm{C}$ in the headspace heater. The SPME fiber was activated prior to use each time by inserting it into the $\mathrm{GC}$ injector at $230 \stackrel{\circ}{\circ} \mathrm{C}$ for $30 \mathrm{~min}$. For sampling, the fiber was inserted in the headspace vial and extracted for $10 \mathrm{~min}$ at $50{ }^{\circ} \mathrm{C}$. Immediately after extraction, the SPME fiber was exposed to the hot GC injection port at $230 \stackrel{\circ}{\circ}$ for $3 \mathrm{~min}$ for desorption of aroma components, where it remained in the inlet during the run, thus preparing it for the next collection of volatiles.

In GC-MS procedure, the injector temperature was set at $230{ }^{\circ} \mathrm{C}$, with desorption time of $3 \mathrm{~min}$. Helium was used as the carrier gas at a flow rate of $1 \mathrm{~mL} / \mathrm{min}$. The components were separated on an Agilent DB-17MS column. The oven temperature program was $50 \stackrel{\circ}{\circ} \mathrm{C}$ for $2 \mathrm{~min}$, increased at $4{ }^{\circ} \mathrm{C} / \mathrm{min}$ to $200{ }^{\circ} \mathrm{C}$, and held isothermally for $5 \mathrm{~min}$,followed by increase at the rate of $15 \stackrel{\circ}{\circ} \mathrm{C} / \mathrm{min}$ to $240{ }^{\circ} \mathrm{C}$, and held isothermally for $5 \mathrm{~min}$. Helium was used as carrier gas. The gas flow rate was set at 1.2 $\mathrm{mL} / \mathrm{min}$ with a splitting ration of 1:35. The GC-MS interface and ion source temperatures were 240 and $200 \stackrel{\circ}{\circ}$, respectively. GC-MS detection was carried out in the complete scanning mode (SCAN) in the range $\mathrm{m} / \mathrm{z} 50-550$. The MS was operated in El mode with standard electron energy of $70 \mathrm{eV}$.

\section{RESULTS}

\section{Pungent components}

The HPLC chromatograms of reference substances are shown in Figure 2, and the regression equation results are shown in Table 1. 


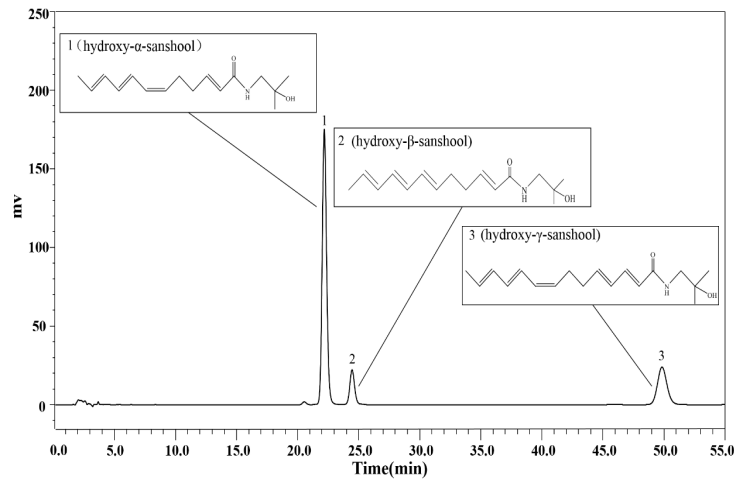

Figure 2: HPLC chromatograms of reference substances. 1: hydroxy-a-sanshool; 2: hydroxy- $\beta$ sanshool; 3:hydroxy-y-sanshool

The peak assignment of each hydroxy sanshool in the sample was based on its retention time in the reference product. The HPLC-DAD chromatograms of samples detected at $270 \mathrm{~nm}$ are shown in Figure 3. The amount of each hydroxy sanshool was quantified with HPLC by comparing the measured peak area with calibration curves obtained from hydroxy- $\alpha$ sanshool, hydroxy- $\beta$-sanshool, and hydroxy- $y-$ sanshool as standards, and the results are summarized in Table 2.

\section{Aroma components}

Extract $(1.0 \mu \mathrm{L})$ was used for the GC-MS analysis. The total ion chromatogram of the GCMS analysis for each sample is shown in Figure 4. Individual constituent were identified by comparison with the internal spectral library of the instruments (Wiley library ver. 9, NIST library ver. 14 and NIST library ver. 14s) and retention times based on references. Statistically, volatile components with a degree of match greater than $90 \%$ were used, and quantitative analysis was based on the relative percentage of normalized peak areas.

A total of 38 components were identified from the volatile components by HS-SPME-GC-MS. The chemical composition and relative contents are shown in Table 3. Linalyl acetate, limonene, linalool, germacrene $\mathrm{D}, \quad \beta$-myrcene, cineole, caryophyllene and $\beta$-phellandrene were the main components, and they comprised more than 81 $\%$ of the total aroma components. In particular, the linalyl acetate constituted 23.53 to $44.95 \%$ (Table 4).

Table 1: Linear regression and sensitivity data

\begin{tabular}{|c|c|c|c|c|c|}
\hline Analyte & 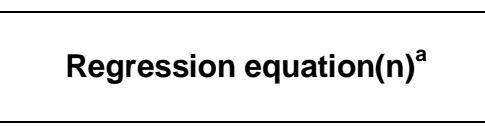 & $\begin{array}{c}\text { Linear } \\
\text { range } \\
(\mu \mathrm{g} / \mathrm{ml})\end{array}$ & $\begin{array}{c}\text { R- } \\
\text { squared }\end{array}$ & $\mathrm{LOQ}(\mathrm{ng} / \mathrm{mL})^{\mathrm{b}}$ & $\operatorname{LOD}(\mathrm{ng} / \mathrm{mL})^{\mathrm{b}}$ \\
\hline $\begin{array}{l}\text { Hydroxy-a- } \\
\text { sanshool }\end{array}$ & $y=82952.5903 x+149089.5000(5)$ & $5.00-80.00$ & 0.9996 & 29.95 & 7.14 \\
\hline $\begin{array}{l}\text { Hydroxy- } \beta \text { - } \\
\text { sanshool }\end{array}$ & $y=132103.8925 x+4226.0833(5)$ & $0.13-2.00$ & 0.9998 & 3.28 & 0.96 \\
\hline Hydroxy- $\gamma$-sanshool & $y=147605.4968 x+1944.7500(5)$ & $0.31-5.00$ & 0.9998 & 21.95 & 6.12 \\
\hline
\end{tabular}

${ }^{\mathrm{a}} \mathrm{y}=$ peak area; $\mathrm{x}=$ concentration of the standard in $(\mu \mathrm{g} / \mathrm{ml}) ; \mathrm{n}=$ number of data points (concentration levels); limits of detection (LOD) and quantitation (LOQ) in $(\mu \mathrm{g} / \mathrm{ml} \mathrm{L})$ and in $(\mathrm{ng})$

Table 2: Content of hydroxy sanshool in the leaves and pericarps of ZBM at different harvest periods

\begin{tabular}{lcccccc}
\hline Analyte & $\begin{array}{c}\text { Young } \\
\text { (May 20) }\end{array}$ & $\begin{array}{c}\text { Half-mature } \\
\text { (June 27) }\end{array}$ & $\begin{array}{c}\text { Mature } \\
\text { (August 8) }\end{array}$ & $\begin{array}{c}\text { Young } \\
\text { (May 20) }\end{array}$ & $\begin{array}{c}\text { Half-mature } \\
\text { (June 27) }\end{array}$ & $\begin{array}{c}\text { Mature } \\
\text { (August 8) }\end{array}$ \\
\hline $\begin{array}{l}\text { Hydroxy- } \alpha- \\
\text { sanshool } \\
\text { (mg/g) }\end{array}$ & $1.93 \pm 0.15$ & $1.18 \pm 0.10$ & $0.89 \pm 0.12$ & $6.78 \pm 0.45$ & $8.99 \pm 0.64$ & $52.70 \pm 2.42$ \\
$\begin{array}{l}\text { Hydroxy- } \beta- \\
\begin{array}{l}\text { sanshool } \\
\text { (mg/g) }\end{array}\end{array}$ & $0.02 \pm 0$ & $0.03 \pm 0.01$ & $0.05 \pm 0.02$ & $0.08 \pm 0.02$ & $0.18 \pm 0.01$ & $0.96 \pm 0.05$ \\
$\begin{array}{l}\text { Hydroxy- }{ }^{*} \\
\text { sanshool } \\
\text { (mg/g) }\end{array}$ & $0.03 \pm 0.01$ & $0.05 \pm 0$ & $0.06 \pm 0.02$ & $0.45 \pm 0.10$ & $1.53 \pm 0.12$ & $11.28 \pm 1.21$ \\
$\begin{array}{l}\text { Total } \\
\text { (mg/g) }\end{array}$ & $1.98 \pm 0.16$ & $1.26 \pm 0.11$ & $1.00 \pm 0.16$ & $7.31 \pm 0.57$ & $10.70 \pm 0.77$ & $64.94 \pm 3.68$ \\
\hline
\end{tabular}

${ }^{*}$ Milligram of hydroxy sanshool per gram of dry sample powder; each value is expressed as mean \pm SD $(n=3$, $\mathrm{mg} / \mathrm{g}$ dry weight) 

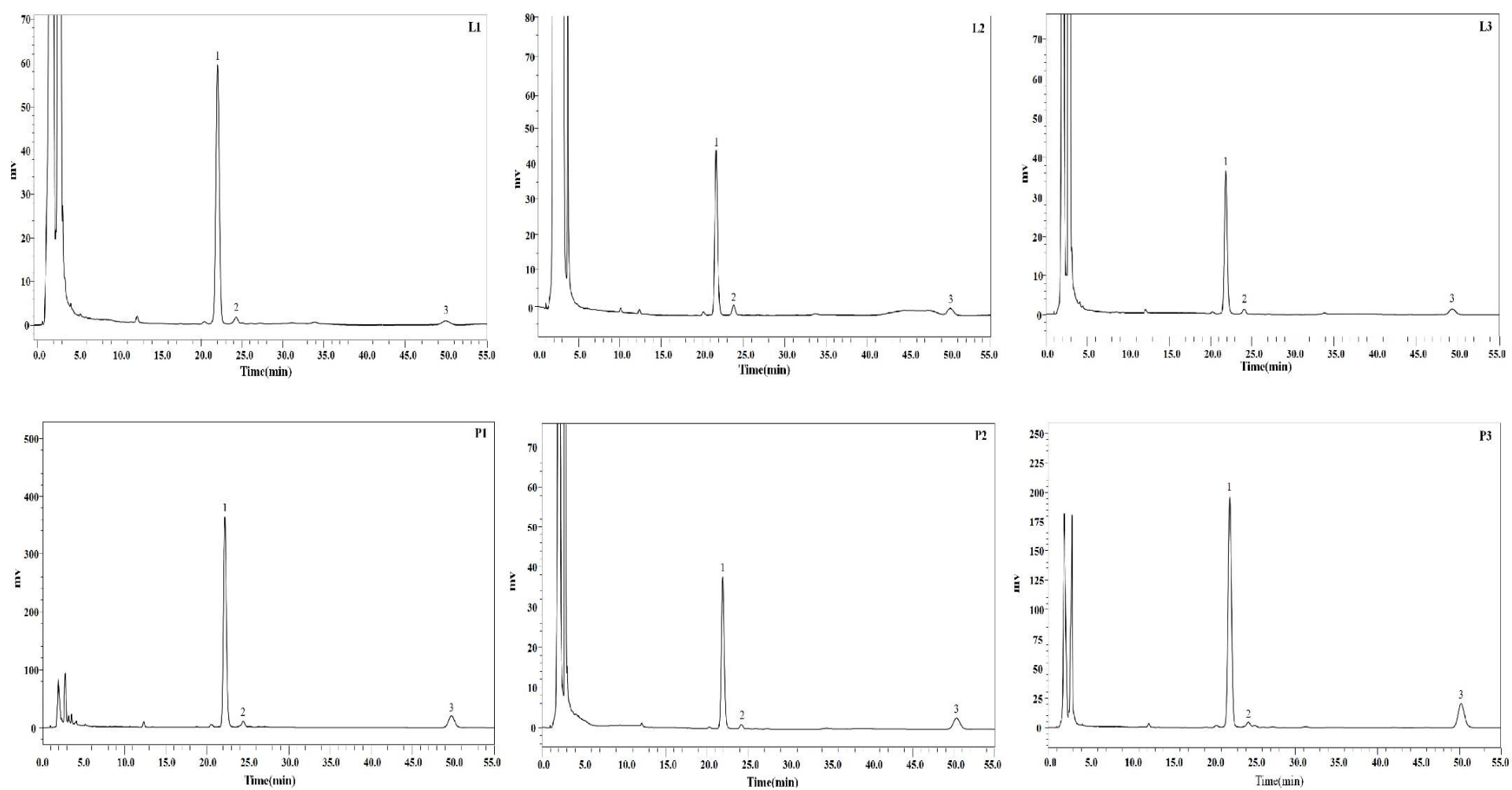

Figure 3: HPLC chromatograms of the samples ( $L 1=$ young leaves; $L 2=$ half-mature leaves; $L 3=$ mature leaves;P1=young pericarps; P2= half-mature pericarps; P3, mature pericarps). 1: hydroxy-a-sanshool; 2:hydroxy$\beta$-sanshool; 3:hydroxy- $\gamma$-sanshool

The aroma constituents comprised mainly monoterpenes and sesquiterpenes, and belong to a structurally diverse group of natural products known as isoprenes. Regardless of the growth monoterpenes content is higher than sesquiterpenines content, and the content is stage of ZBM leaves and pericarps, its more than $70 \%$ (Table 5).

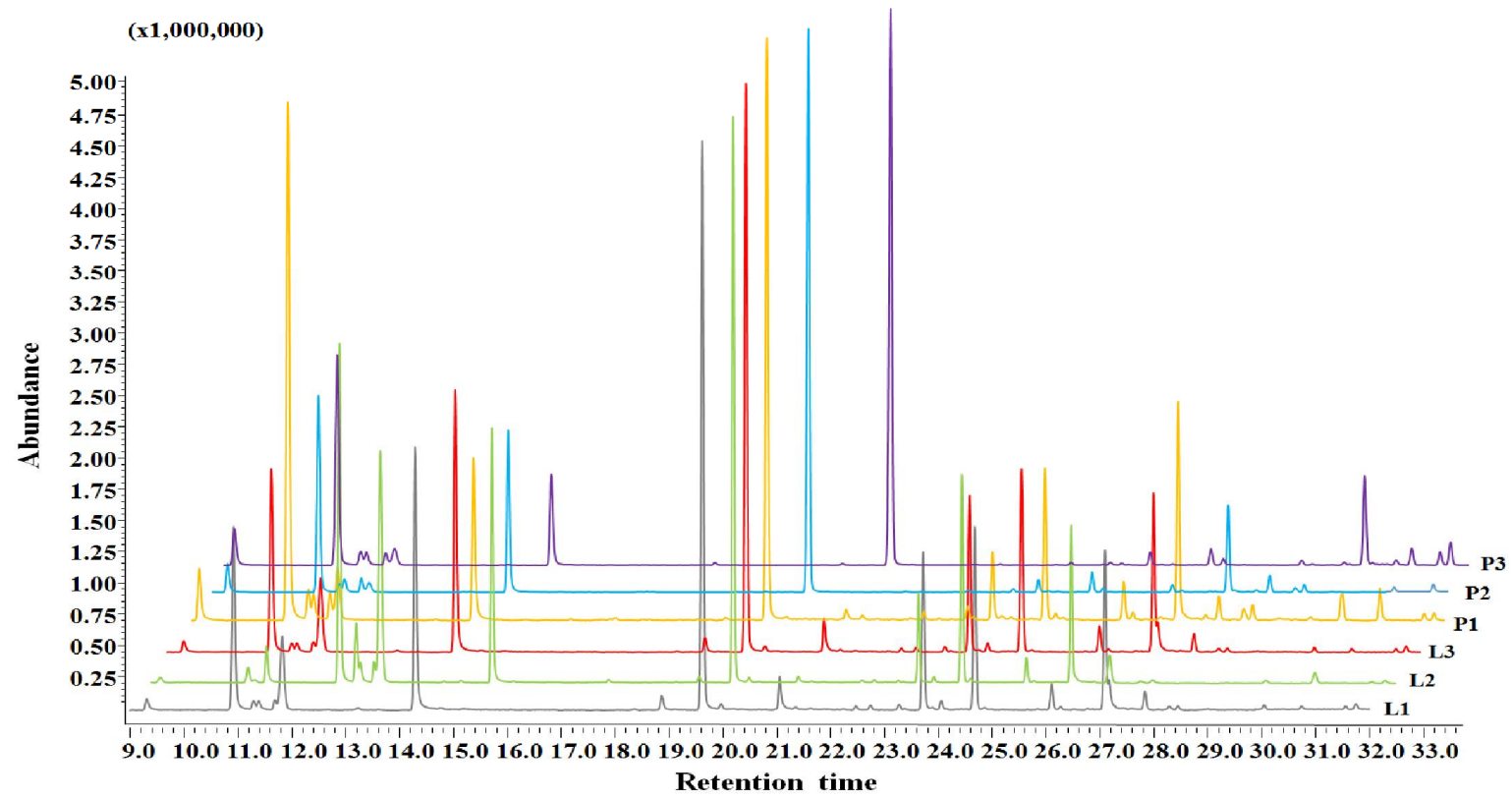

Figure 4: Total ion chromatogram of volatile components in the leaves and pericarps of ZBM at different harvest times: $L 1$ = young leaves; $L 2$ = half-mature leaves; $L 3=$ mature leaves; $P 1$ = young pericarps; $P 2$ = half-mature pericarps; P3 = mature pericarps 
Table 3: Volatile constituents of the leaves and pericarps of ZBM at different harvest periods

\begin{tabular}{|c|c|c|c|c|c|c|c|c|}
\hline \multirow{2}{*}{ No. } & \multirow{2}{*}{$\begin{array}{l}\text { Retention time } \\
\text { (min) }\end{array}$} & \multirow{2}{*}{ Compound } & \multicolumn{6}{|c|}{ Relative content (\%) } \\
\hline & & & L1 & L2 & L3 & $P 1$ & $P 2$ & P3 \\
\hline 1 & 9.15 & $\alpha$-Pinene & - & 0.37 & - & - & - & - \\
\hline 2 & 11.05 & Sabinene & - & 0.89 & - & - & - & - \\
\hline 3 & 11.20 & $\beta$-Pinene & - & 0.18 & - & - & - & - \\
\hline 4 & 11.74 & $\beta$-myrcene & 3.03 & 1.88 & 0.73 & 2.72 & 2.73 & 3.68 \\
\hline 5 & 13.14 & Limonene & 26.42 & 17.41 & 14.40 & 27.25 & 20.35 & 19.02 \\
\hline 6 & 13.47 & $\beta$-phellandrene & 3.12 & 3.09 & 0.51 & 1.67 & 1.31 & 0.78 \\
\hline 7 & 13.89 & Trans- $\beta$-Ocimene & 1.03 & 0.94 & 0.58 & 1.31 & 1.20 & 1.19 \\
\hline 8 & 14.79 & $\beta$-Ocimene & 0.90 & 0.93 & 0.54 & 1.33 & 1.26 & 1.09 \\
\hline 9 & 15.01 & Cineole & 1.97 & 15.18 & 7.95 & 3.57 & 2.21 & 1.23 \\
\hline 10 & 16.33 & Linalool & 9.58 & 11.29 & 14.84 & 7.54 & 8.01 & 10.73 \\
\hline 11 & 18.86 & Citronellal & 1.12 & 0.13 & - & - & - & 0.20 \\
\hline 12 & 20.82 & a-Terpineol & 0.26 & 0.27 & 0.82 & - & - & 0.11 \\
\hline 13 & 21.57 & Linalyl acetate & 36.58 & 24.75 & 23.53 & 24.06 & 44.61 & 44.95 \\
\hline 14 & 21.90 & y-Terpinene & - & 0.18 & 0.36 & - & - & - \\
\hline 15 & 22.97 & 2-Hendecanone & - & 0.24 & 2.09 & 0.46 & - & - \\
\hline 16 & 23.26 & a.-Cubebene & 0.15 & - & - & 0.17 & - & - \\
\hline 17 & 24.35 & $\alpha$-Copaene & 0.33 & 0.08 & 0.20 & 0.38 & 0.23 & 0.15 \\
\hline 18 & 24.62 & 4-Terpinenyl acetate & - & 0.11 & 0.22 & - & - & - \\
\hline 19 & 24.84 & Citronellyl acetate & 0.26 & - & - & 一 & 一 & 0.05 \\
\hline 20 & 25.14 & $\beta$-Cubebene & 0.12 & 0.09 & 0.29 & 0.62 & 0.25 & 0.14 \\
\hline 21 & 25.24 & $\beta$-Elemene & 0.08 & - & - & 0.15 & - & - \\
\hline 22 & 25.58 & Terpinyl acetate & 0.08 & 0.11 & 8.26 & 3.01 & 1.09 & 0.98 \\
\hline 23 & 25.74 & a-Gurjunene & - & 0.23 & 0.23 & 0.23 & - & - \\
\hline 24 & 26.51 & Caryophyllene & 3.56 & 9.40 & 10.90 & 7.10 & 1.67 & 1.40 \\
\hline 25 & 26.70 & Geranyl acetate & 1.35 & 0.23 & 0.13 & 0.36 & 0.51 & 0.33 \\
\hline 26 & 27.91 & a-Humulene & 0.62 & 1.10 & 1.37 & 1.98 & 0.63 & 0.41 \\
\hline 27 & 28.07 & Aromadendrene & - & - & 0.15 & 0.35 & 0.14 & 0.09 \\
\hline 28 & 28.56 & y-Muurolene & 0.14 & - & - & - & 0.14 & 0.24 \\
\hline 29 & 28.88 & Germacrene D & 4.07 & 7.04 & 8.25 & 9.91 & 7.56 & 7.29 \\
\hline 30 & 29.00 & a-Farnesene & 0.13 & - & - & - & 0.16 & 0.13 \\
\hline 31 & 29.37 & a-Muurolene & 0.25 & - & - & 0.18 & 0.20 & 0.24 \\
\hline 32 & 29.61 & Bicyclogermacrene & 0.51 & 1.12 & 1.00 & 1.06 & 1.38 & 1.43 \\
\hline 33 & 30.05 & $\mathrm{Y}$-cadinene & 0.78 & - & 0.27 & 0.62 & 0.41 & 1.19 \\
\hline 34 & 30.21 & $\delta$-cadinene & 1.18 & 0.11 & 0.27 & 0.70 & 0.57 & 1.94 \\
\hline 35 & 31.79 & Germacrene B & 0.10 & 0.11 & 0.19 & 1.19 & 0.35 & 0.20 \\
\hline 36 & 34.27 & Spathulenol & - & - & 0.16 & 0.28 & - & - \\
\hline 37 & 32.47 & Cubebol & - & 0.42 & 0.16 & 1.42 & 0.66 & 一 \\
\hline 38 & 33.45 & Caryophyllene oxide & 0.11 & 0.10 & 0.28 & 0.29 & - & - \\
\hline
\end{tabular}

L1, L2, and L3 represent samples of young leaves, half-leaves, and mature leaves, respectively; P1, P2, and P3 represent young pericarps, half-mature pericarps, and mature pericarps samples, respectively; "-" represents not detected

Table 4: Major compounds of the leaves and pericarps of ZBM collected during different seasons

\begin{tabular}{lcccccc}
\hline \multirow{2}{*}{ Compound } & \multicolumn{7}{c}{ Relative content (\%) } \\
\cline { 2 - 6 } & $\mathbf{L 1}$ & $\boldsymbol{L 2}$ & $\boldsymbol{L 3}$ & $\boldsymbol{P 1}$ & $\boldsymbol{P 2}$ & $\boldsymbol{P 3}$ \\
\hline Linalyl acetate & 36.58 & 24.75 & 23.53 & 24.06 & 44.61 & 44.95 \\
Limonene & 26.42 & 17.41 & 14.40 & 27.25 & 20.35 & 19.02 \\
Linalool & 9.58 & 11.29 & 14.84 & 7.54 & 8.01 & 10.73 \\
Germacrene D & 4.07 & 7.04 & 8.25 & 9.91 & 7.56 & 7.29 \\
B-myrcene & 3.03 & 1.88 & 0.73 & 2.72 & 2.73 & 3.68 \\
Cineole & 1.97 & 15.18 & 7.95 & 3.57 & 2.12 & 1.23 \\
Caryophyllene & 3.56 & 9.4 & 10.9 & 7.1 & 1.67 & 1.4 \\
B-phellandrene & 3.12 & 3.09 & 0.51 & 1.67 & 1.31 & 0.78 \\
Total & 88.33 & 90.04 & 81.11 & 83.82 & 88.36 & 89.08 \\
\hline
\end{tabular}

L1, L2, and L3 represent samples of young leaves, half-leaves, and mature leaves, respectively; P1, P2, and P3 represent young pericarps, half-mature pericarps, and mature pericarps samples, respectively 
Table 5: Relative contents of monoterpenes and sesquiterpenes in leaves and pericarps of ZBM at different harvest periods

\begin{tabular}{ccccccc}
\hline Monoterpe & \multicolumn{6}{c}{ Relative content (\%) } \\
\cline { 2 - 7 } noids & L1 & L2 & L3 & P1 & P2 & P3 \\
\hline Monoterpen & 85. & 76. & 76. & 73. & 83. & 83. \\
es & 70 & 46 & 18 & 28 & 19 & 34 \\
Sesquiterpe & 12. & 19. & 23. & 26. & 15. & 13. \\
nes & 13 & 80 & 72 & 63 & 54 & 95
\end{tabular}

L1, L2, and L3 represent samples young leaves, halfleaves, and mature leaves, respectively; P1, P2, and P3 represent young pericarps, half-mature pericarps, and mature pericarps samples, respectively

\section{DISCUSSION}

The results of this study suggest that the pungent components in the leaves and pericarps of ZBM were same basically. However, the content of pungent components in the leaves was less than that of pericarps. At different periods, hydroxy- $\alpha$ sanshool was the most abundant pungent component in the leaves and pericarps of ZBM, followed by hydroxy- $\gamma$-sanshool and hydroxy- $\beta$ sanshool. However, in the previous studies regarding pungent substances in other genus Zanthoxylum (Rutaceae), such as $Z$. schinifolium and Xanthoxylum piperitum, hydroxy- $\alpha$-sanshool and hydroxy- $\beta$-sanshool were considered to be the most important pungent components, and the hydroxy- $y$-sanshool was not a major pungent component $[10,11]$.

Therefore, hydroxy-y-sanshool may be a characteristic pungent component of ZBM, unlike what was reported in other Zanthoxylum varieties. In addition, it was found that during the growth of ZBM, the pungent substances in the leaves were reduced gradually, while those in the pericarps were increased continuously, indicating that these substances were gradually translocated from the leaves to the pericarps during this process.

The HS-SPME-GC-MS has advantages of simplicity, rapidity and high-efficiency in the analysis of volatile constituents from leaves and pericarps of ZBM [12]. Linalyl acetate, linalool, and limonene were the major components of the leaves and pericarps of ZBM. This is consistent with the results of previous studies [13]. In addition, the aroma components of the leaves and pericarps were generally similar. However seasonal changes could affect the contents of main constituents in the leaves and pericarps of ZBM.

The main aroma components in the pericarps and leaves of ZBM are monoterpenes. Similar to the pungent substances, the monoterpene contents decreased gradually in the leaves, but increased in the pericarps, suggesting that the monoterpenes in leaves could be transferred to the pericarps continuously following the growth and development of ZBM. However, in a different study, it was reported that the essential oil of $Z$. piperitum was rich in monoterpenes at the early stages, but changed to being enriched with sesquiterpenes at the maturation stages [14]. These differences in results may be related to differences in the varieties of Zanthoxylum used.

\section{CONCLUSION}

The results obtained in this study indicate that the pungent and aroma components produced from ZBM leaves at the early developmental stages are stored in leaves, and are transferred to the pericarps at the final developmental stages. The hydroxyl sanshool level in the pericarps of ZBM gradually increases, and the content and distribution of the aroma components also change during maturation of the pericarps. These changes in pungency and fragrance during maturation appear to support the use of both species as sources of huajiao in traditional Chines medicine. These results provide a basis for selecting an appropriate harvest time for the pericarps and leaves, as well as afford a reference for their quality control. The results also provide a useful basis for the development and utilization of leaves and pericarps of ZBM as value-added food and medicinal resource.

\section{DECLARATIONS}

\section{Acknowledgement}

This work was supported by the Project of Administration of Traditional Chinese Medicine of Sichuan Province of China (no. 2018JC001) and Sichuan Provincial Department of Education Project (no.16TD0014).

\section{Conflict of interest}

No conflict of interest is associated with this work.

\section{Contribution of authors}

We declare that this work was done by the authors named in this article and all liabilities pertaining to claims relating to the content of this article will be borne by the authors. C.-J. Wu conceived the research. L. Zhu., L. Wang., X. Chen., and F. Liang performed the detail experiments. L. Zhu collected test data and 
drafted the manuscript. L. Wang and $X$. Chen. analyzed the data. W. Peng and Y.-J. Liu contributed reagents/materials/analysis tools. W. Peng and L.-Y. Yu revised the manuscript.

\section{REFERENCES}

1. Zhang $M$, Wang J, Zhu L, Li T, Jiang W, Zhou J, Peng W, Wu $C$. Zanthoxylum bungeanum maxim. (rutaceae): $A$ systematic review of its traditional uses, botany, phytochemistry, pharmacology, pharmacokinetics, and toxicology. Int J Mol Sci 2017; 18.14214

2. Ye Q. Rapid analysis of the essential oil components of dried Zanthoxylum bungeanum Maxim by Fe2O3magnetic-microsphere-assisted microwave distillation and simultaneous headspace single-drop microextraction followed by GC-MS. J Sep Sci. 2013; 36(12): 2028-2034.

3. Li K, Zhou R, Wang Jia W, Li Z, Li J, Zhang P, Xiao T. Zanthoxylum bungeanum essential oil induces apoptosis of HaCaT human keratinocytes. J Ethnopharmacol. 2016; 186: 351-361.

4. Artaria C, Maramaldi G, Bonfigli A, Rigano L, Appendino G. Lifting properties of the alkamide fraction from the fruit husks of Zanthoxylum bungeanum. Int $\mathrm{J}$ Cosmet Sci. 2011; 33(4): 328-333.

5. Kubota K, Ohtake N, Ohbuchi K, Mase A, Imamura S, Sudo $Y$, Miyano K, Yamamoto $M$, Kono $T$, Uezono $Y$. Hydroxy-alpha sanshool induces colonic motor activity in rat proximal colon: a possible involvement of KCNK9. Am J Physiol Gastrointest Liver Physiol. 2015; 308(7): G579-590.

6. You Y, Zhou M, Lu H, Shirima GG, Cheng Y, Liu X. Sanshool from Zanthoxylum $L$. induces apoptosis in human hepatocarcinoma HepG2 cells. Food Science and Biotechnology.2015; 24: 2169-2175.
7. Rong R, Cui MY, Zhang QL, Zhang MY, Yu YM, Zhou $X Y, Y u Z G$, Zhao YL (2016) Anesthetic constituents of Zanthoxylum bungeanum Maxim.: A pharmacokinetic study. J Sep Sci. 2016; 39: 2728-2735.

8. Mizutani K, Fukunaga $Y$, Tanaka O, Takasugi N, Saruwatari YI, Fuwa T, Yamauchi T, Wang J, Jia MR, Li FY. Amides from huajiao, pericarps of Zanthoxylum bungeanum MAXIM. Chem Pharm Bull 1988;36: 23622365.

9. Cui EY, Zhao YL, Wang T, Zhou HY, Li EQ, Zhi-Guo YU, Pharmacy SO. Simultaneous determination of three sanshools in Zanthoxylum bungeanum Maxim. extract by RP-HPLC. J Shenyang Pharm Univ. 2014; 31(4): 272-275.

10. Sugai E, Morimitsu YK. Quantitative analysis of sanshool compounds in Japanese pepper (Xanthoxylum piperitum dc.) and their pungent characteristics. Biosci, Biotechnol Biochem 2005; 69(10): 1958-1962.

11. Iseli V, Potterat O, Hagmann L, Egli J, Hamburger M. Characterization of the pungent principles and the essential oil of Zanthoxylum schinifolium pericarp. Die Pharmazie 2007; 62(5): 396.

12. Wei S, Zhang $H$, Wang $Y$, Wang L, Li X, Wang $Y$, Zhang $H$, Xu $X$, Shi $Y$. Ultrasonic nebulization extractionheating gas flow transfer-headspace single drop microextraction of essential oil from pericarp of Zanthoxylum bungeanum Maxim. J Chromatogr $A$. 2011; 1218(29): 4599-4605.

13. Yang $X$. Aroma constituents and alkylamides of red and green huajiao (Zanthoxylum bungeanum and Zanthoxylum schinifolium). J Agric Food Chem 2008; 56(5): 1689-1696.

14. Kim JH. Seasonal variations in the content and composition of essential oil from Zanthoxylum piperitum. J Ecol Environ 2012; 35(35): 195-201. 